\title{
Identification and Quantification of Microbial Contaminations Present in Herbal Medicines Commonly Consumed by Women in Riyadh, Saudi Arabia
}

\author{
Muneera D. F. Al Kahtani \\ Department of Biology, College of Science, Princess Nora Bint Abdul Rahman University, Riyadh, Saudi Arabia \\ Email: sijbssubscription@gmail.com,mdf.alkahtani@gmail.com
}

How to cite this paper: $\mathrm{Al} \mathrm{Kahtani,} \mathrm{M.D.F.}$ (2017) Identification and Quantification of Microbial Contaminations Present in Herbal Medicines Commonly Consumed by Women in Riyadh, Saudi Arabia. Journal of Agricultural Chemistry and Environment, 6, 83-92.

https://doi.org/10.4236/jacen.2017.61005

Received: November 28, 2016

Accepted: January 21, 2017

Published: January 24, 2017

Copyright $\odot 2017$ by author and Scientific Research Publishing Inc. This work is licensed under the Creative Commons Attribution International License (CC BY 4.0).

http://creativecommons.org/licenses/by/4.0/

\begin{abstract}
The present study aimed to investigate the microbial populations such a bacteria and fungi contamination present in the herbal medicinal preparations (Lepidium sativum, Nigella sativa, Cuminum cyminum, Foeniculum vulgare, Pimpinella anisum, Trigoneela foenum-graecum, Cinnamomum verum, peel coffee, Alchemilla valgaris, Vitex agnus-castus) commonly available in different parts of Riyadh, Saudi Arabia. To determine the contamination of the herbal products, experiments such as total aerobic bacterial plate counts were evaluated by various plating techniques. The isolation and identification of fungi were done using czapek dox agar and potato dextrose agar. The results showed that a total of herbal remedies were contaminated with bacteria and fungi (100\%). Among the contaminated products, peel of coffee and Vitex angnus-castus were noted more contamination than the other herbal medicinal plants. The results confirmed that the traditionally prepared herbal medications in Riyadh city are likely to be contaminated with a wide variety of potentially pathogenic bacteria and fungi. Therefore, before consumption, the quality assurance of these products should be thoroughly enforced and monitored in the production and distribution of herbal preparations. In conclusion, the present study gives proper evidence that the consumed herbal products contain different levels of pathogenic microbes.
\end{abstract}

\section{Keywords}

Traditional Medicinal Plants, Bacterial Contamination, Fungal Contamination, Identification 


\section{Introduction}

Postpartum period has been influenced by multiple cultural beliefs and practices transmitted from generation to generation. Some traditional practices are beneficial to the mother and baby, whereas others are not. Therefore it is essential for planning and implementing health education programs for these women to realize the beneficial and harmless practices. Postpartum period is the period beginning immediately after the birth of a baby and extending for about six weeks. It is the time during which the mother's body including hormonal levels and general and reproductive systems returns to a non-pregnant state [1]. Postpartum period is one of the most important stages for the mother-child dichotomy, and has been influenced by multiple cultural beliefs and practices transmitted from generation to generation. Internationally, many studies described the traditional beliefs and practices surrounding child bearing process. Some traditional practices are beneficial to the mother and baby, whereas other practices are not [2] [3] [4]. Traditional postpartum beliefs and practices are common in many countries. Among that, one common belief in many non-Western cultures is the necessity of maintaining a "hot-cold balance" within the body after the birth of a baby. Accordingly, in some cultures, traditional midwives emphasize the application of heat in the postpartum period. New mothers are instructed to use heated water to preserve their warmth by taking the herbal bath, according to the region. They believed that a hot bath increases the flow of milk, and prevents breast milk from becoming "cold". The history of using herbal medicines is inextricably intertwined with that of modern medicine [5]. Many synthetic drugs listed as conventional medication were originally derived from plants. Traditional herbal plants use various herbal preparations to treat various types of ailments, including diarrhea, urinary tract infections, typhoid fever and skin diseases [6] [7] [8]. Most of the herbal preparations are used in different forms and may carry a large number of various kinds of microbes originating from soil usually adhering to leaves, stems, flowers, seed and root of the herbs [9] [10] [11]. The World Health Organization (WHO 1998) survey indicated that about $70 \%-80 \%$ of the world population particularly in developing countries relies on non-conventional medicines mainly of herbal origins for their primary health care [12]. This is because herbal medicines are accessible and cheap [13] [14]. Therefore, the quality and safety of herbal preparations are also of great concern. The WHO (1993) explained that quality is the basis of reproducible efficacy and safety of herbal drugs, and to ensure the standard of research on herbal medicines, the quality of the plant materials or preparations is of utmost importance [12]. It has been showed that the quality criteria for herbal drugs are based on a clear scientific definition of the raw materials. It is difficult to establish comprehensive quality criteria for herbal drugs due to "professional secrecy"' of herbalists, but in order to improve the purity and safety of the products, observation of basic hygiene during preparation, standardization of some physical characteristics such as moisture content, $\mathrm{pH}$ and microbiological contamination levels is desirable. Previous studies have confirmed the presence of potential contami- 
nants in herbal preparations [15]. The contaminants that present serious health hazard are pathogenic bacteria such as Salmonella species, Escherichia coli, Staphylococcus aureus, Shigella spp. and other Gram positive and Gram negative strains of bacteria [16] [17]. Unfortunately, no researches (to the best of our knowledge) have been carried out to determine the microbiological safety of these herbal products. In this paper, the level of contamination of powdered herbal products marketed in Riyadh city with selected pathogenic bacteria and fungi was determined and also the antimicrobial susceptibility pattern of these identified microbial pathogens were determined.

\section{Materials and Methods}

\subsection{Study Area and Sampling}

A total of 10 different herbal preparations were purchased randomly from herbal shops in Riyadh city. Packaged herbal samples were collected and taken to the laboratory, while those that were not packaged (such as herbal preparations sold by local herbalist) were collected in sterile cans glass [18]. All samples collected from the sites were analyzed in the laboratories of Department of Biology, Prinses Noura University, Saudi Arabia.

\subsection{Preparation of Culturing Media}

All dehydrated media were prepared according to manufacturer's instructions. They were mixed with distilled water and dissolved by gentle heat to boil. The media were sterilized in an autoclave (LTE J7090 model, LTE Scientific Ltd., England) at $121^{\circ} \mathrm{C}$ for $15 \mathrm{~min}$. The sterile media were dispensed or poured into sterilized petri dishes and allowed to cool. The sterility of the prepared media was checked by incubation of blindly selected plates at $37^{\circ} \mathrm{C}$ for $24 \mathrm{~h}$.

\subsection{Isolation and Identification of Bacteria}

A stock solution of the each sample was prepared by weighing one gram $(1 \mathrm{~g})$ of the sample into $9 \mathrm{~mL}$ of sterile water and shaken thoroughly. A ten-fold serial dilution of the bacterial suspension was made. This was done until $10^{-4}$ dilution was achieved. $1 \mathrm{~mL}$ was then pipetted from the $10^{-4}$ dilution onto the surface of each of two inoculated onto blood agar and nutrient agar media and incubated aerobically at $37^{\circ} \mathrm{C}$ for maximum up to $48 \mathrm{~h}$, and repetition three times to ensure the counting of the bacterial colonies.

\subsection{Isolation and Identification of Fungi}

For the isolation of fungal strains 1 gram from each sample and inoculated onto two media czapek dox agar and potato dextrose agar and incubated at $25^{\circ} \mathrm{C}$ for 4 days.

\subsection{Data Statistical Analysis}

The obtained data were statistically analyzed using the Analysis of Variance 
(ANOVA) with one way with the MSTAT-C statistical package. The least significant difference procedure (LSD) was used at 0.05 level of probability.

\section{Results and Discussion}

The results of the moisture content showed that there was remarkable variation among the different herbal preparations sampled. European Agency for the Evaluation of Medicinal products (1998) suggested that water content should be included in the list of comprehensive specifications for herbal medicinal products especially the powdered forms [19]. The maximum moisture content limit of $8 \% / g$ of herbal preparations are satisfactory according to National Agency for Food and Drug Administration and Control (NAFDAC SOP 2000) [20]. In this study, (100\%) of the 10 herbal products were within, while 5 (50\%) were outside the NAFDAC stated limit. Even at less than $58 \%$ moisture content limit various pathogenic bacteria were found. The fungi counts observed in the (100\%) herbal preparations with high moisture contents were high, suggesting that high moisture contents favored the growth of pathogenic bacteria as well as non-pathogenic ones in herbal preparations. Similarly, the low bacterial counts in the other preparations could be attributed to very low moisture contents. In order to ascertain the correlation between the moisture content and bacterial load, Pearson chi-square correlation test was employed. At 0.01 level of confidence there was positive correlation between moisture content and bacterial counts $(\mathrm{r}=+0.109)$.

As shown in Table 1 and Table 2 and Figure 1, there were no statistically significant differences at the level of 0.05 or less for plant samples (Lepidium sativum, Nigella sativa, Cuminum cyminum, Foeniculum vulgar, Pimpinella animus, Trigoneela foenum-graecum, Cinnamomum verum, Alchemilla valgaris). As it is clear from the results shown in Table 1 , there are no statistically significant differences at the 0.05 level or less about (peel coffee) variable depending on the study. It is clear from the results described above and no statistically significant differences at the level of about 0.01 or less (Vitex agnus-castus) variable depending on the study. In order to determine the direction of the differences between each of the two study groups towards the direction on these axes were used "LSD" test and the results were illustrated in Figure 1 and Figure 2.

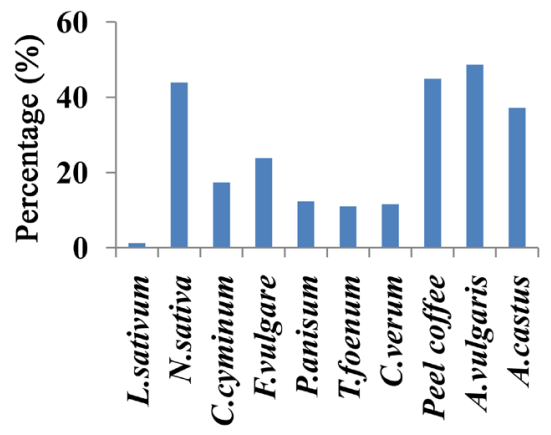

Figure 1. Percentage of the growth bacteria and fungi isolation from herbal medicine. 


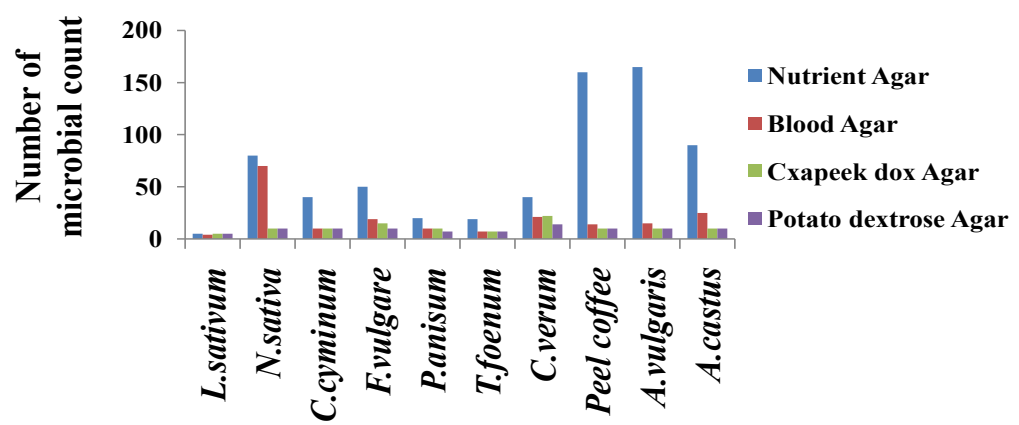

Figure 2. Range of the growth bacteria and fungi isolation from herbal medicine in different media.

Table 1. Average bacteria and fungi count of sample ( $\times 104 \mathrm{CFU} / \mathrm{g})$.

\begin{tabular}{|c|c|c|c|c|c|c|}
\hline & & Sum of squares & df & Mean Square & $\mathbf{F}$ & Significance \\
\hline \multirow[t]{3}{*}{$\mathrm{A} 1$} & Between Groups & 18.917 & 3 & 6.306 & 2.162 & 0.171 \\
\hline & With in Groups & 23.333 & 8 & 2.917 & & \\
\hline & Total & 42.25 & 11 & & & \\
\hline \multirow[t]{3}{*}{ A2 } & Between Groups & $16,988.25$ & 3 & 5662.750 & 2.725 & 0.114 \\
\hline & With in Groups & $16,626.667$ & 8 & 2078.333 & & \\
\hline & Total & $33,614.917$ & 11 & & & \\
\hline \multirow[t]{3}{*}{$\mathrm{A} 3$} & Between Groups & 23.12 .00 & 3 & 770.667 & 2.369 & 0.147 \\
\hline & With in Groups & 2602.667 & 8 & 325.333 & & \\
\hline & Total & 4914.667 & 11 & & & \\
\hline \multirow[t]{3}{*}{ A4 } & Between Groups & 4387.000 & 3 & 1462.333 & 1.926 & 0.204 \\
\hline & With in Groups & 6074.667 & 8 & 759.333 & & \\
\hline & Total & $10,461.667$ & 11 & & & \\
\hline \multirow[t]{3}{*}{ A5 } & Between Groups & 196.00 & 3 & 65.333 & 0.547 & 0.664 \\
\hline & With in Groups & 954.667 & 8 & 119.333 & & \\
\hline & Total & 1150.667 & 11 & & & \\
\hline \multirow[t]{3}{*}{ A6 } & Between Groups & 448.667 & 3 & 149.556 & 0.646 & 0.607 \\
\hline & With in Groups & 1851.333 & 8 & 231.417 & & \\
\hline & Total & 2300.000 & 11 & & & \\
\hline \multirow[t]{3}{*}{ A7 } & Between Groups & 2593.667 & 3 & 864.556 & 2.673 & 0.118 \\
\hline & With in Groups & 2587.333 & 8 & 323.417 & & \\
\hline & Total & 5181.000 & 11 & & & \\
\hline \multirow[t]{3}{*}{ A8 } & Between Groups & $53,020.250$ & 3 & $17,673.417$ & 4.524 & 0.039 \\
\hline & With in Groups & $31,250.667$ & 8 & 3906.333 & & \\
\hline & Total & $84,270.917$ & 11 & & & \\
\hline \multirow[t]{3}{*}{ A9 } & Between Groups & $57,842.000$ & 3 & $19,280.667$ & 3.540 & 0.068 \\
\hline & With in Groups & $43,572.667$ & 8 & 5446.583 & & \\
\hline & Total & $101,414.7$ & 11 & & & \\
\hline \multirow[t]{3}{*}{ A 10} & Between Groups & $22,177.000$ & 3 & 7392.333 & 23.630 & 0.000 \\
\hline & With in Groups & 2502.667 & 8 & 312.833 & & \\
\hline & Total & $24,679.667$ & 11 & & & \\
\hline
\end{tabular}


Table 2. Occurrence and frequency of fungi and bacteria with herbal medicine of four different media.

\begin{tabular}{|c|c|c|c|c|c|c|c|}
\hline \multirow[b]{2}{*}{$\begin{array}{c}\text { Dependant } \\
\text { Variable }\end{array}$} & \multirow[b]{2}{*}{$1 \mathrm{Q} 2$} & \multicolumn{2}{|l|}{ LSD } & \multirow[b]{2}{*}{$\begin{array}{l}\text { Standard } \\
\text { error }\end{array}$} & \multirow[b]{2}{*}{ Significance } & \multicolumn{2}{|c|}{$\begin{array}{c}95 \% \\
\text { confidence } \\
\text { interval }\end{array}$} \\
\hline & & JQ2 & $\begin{array}{c}\text { Mean } \\
\text { Difference } \\
(\mathrm{I}-\mathrm{J})\end{array}$ & & & $\begin{array}{l}\text { Lower } \\
\text { Bound }\end{array}$ & $\begin{array}{l}\text { Upper } \\
\text { Bound }\end{array}$ \\
\hline \multirow[t]{12}{*}{ A8 } & Nutrient Agar & Blood Agar & $150.33^{*}$ & 51.03 & 0.019 & 32.65 & 268.01 \\
\hline & & Czapek dox Agar & $155.00^{*}$ & 51.03 & 0.016 & 37.32 & 272.68 \\
\hline & & $\begin{array}{c}\text { Potato dextrose } \\
\text { Agar }\end{array}$ & $155.00^{\star}$ & 51.03 & 0.016 & 37.32 & 272.68 \\
\hline & Blood Agar & Nutrient Agar & $-150.33^{\star}$ & 51.03 & 0.019 & -268.01 & -32.65 \\
\hline & & Czapek dox Agar & 4.67 & 51.03 & 0.929 & -113.01 & 122.35 \\
\hline & & $\begin{array}{c}\text { Potato dextrose } \\
\text { Agar }\end{array}$ & 4.67 & 51.03 & 0.929 & -113.01 & 122.35 \\
\hline & $\begin{array}{l}\text { Czapek dox } \\
\text { Agar }\end{array}$ & Nutrient Agar & $-150.33^{\star}$ & 51.03 & 0.016 & -272.68 & -37.32 \\
\hline & & Blood Agar & -4.67 & 51.03 & 0.929 & -122.35 & 113.01 \\
\hline & & $\begin{array}{c}\text { Potato dextrose } \\
\text { Agar }\end{array}$ & 0.00 & 51.03 & 1.000 & -117.68 & 117.68 \\
\hline & $\begin{array}{c}\text { Potato dextrose } \\
\text { Agar }\end{array}$ & Nutrient Agar & $-150.33^{\star}$ & 51.03 & 0.016 & -272.68 & -37.32 \\
\hline & & Blood Agar & -4.67 & 51.03 & 0.929 & -122.35 & 113.01 \\
\hline & & Czapek dox Agar & 0.00 & 51.03 & 1.000 & -117.68 & 117.68 \\
\hline \multirow[t]{12}{*}{ A 10} & Nutrient Agar & Blood Agar & $80.67^{\star}$ & 14.44 & 0.001 & 47.36 & 113.97 \\
\hline & & Czapek dox Agar & $104.67^{*}$ & 14.44 & 0.000 & 71.36 & 137.97 \\
\hline & & $\begin{array}{c}\text { Potato dextrose } \\
\text { Agar }\end{array}$ & $104.67^{\star}$ & 14.44 & 0.000 & 71.36 & 137.97 \\
\hline & Blood Agar & Nutrient Agar & $-80.67^{\star}$ & 14.44 & 0.001 & -113.97 & -47.36 \\
\hline & & Czapek dox Agar & 24.00 & 14.44 & 0.135 & -9.30 & 57.30 \\
\hline & & $\begin{array}{c}\text { Potato dextrose } \\
\text { Agar }\end{array}$ & 24.00 & 14.44 & 0.135 & -9.30 & 57.30 \\
\hline & $\begin{array}{c}\text { Czapek dox } \\
\text { Agar }\end{array}$ & Nutrient Agar & $-104.67^{\star}$ & 14.44 & 0.000 & -137.97 & -71.36 \\
\hline & & Blood Agar & -24.00 & 14.44 & 0.135 & -57.30 & 9.30 \\
\hline & & $\begin{array}{c}\text { Potato dextrose } \\
\text { Agar }\end{array}$ & 0.00 & 14.44 & 1.000 & -33.30 & 33.30 \\
\hline & $\begin{array}{c}\text { Potato } \\
\text { dextrose Agar }\end{array}$ & Nutrient Agar & $-104.67^{\star}$ & 14.44 & 0.000 & -137.97 & -71.36 \\
\hline & & Blood Agar & -24.00 & 14.44 & 0.135 & -57.30 & 9.30 \\
\hline & & Czapek dox Agar & 0.00 & 14.44 & 1.000 & -33.30 & 33.30 \\
\hline
\end{tabular}

${ }^{*}$ The mean difference is significance at the 0.05 level.

The microbial populations were not significant with the medicinal plants such as (peel coffee) in (nutrient agar) and the medium in the (blood agar, czapek dox agar, potato dextrose agar) (Table 3). As it is clear from the results described 
Table 3. Frequency of the fungi and bacteria isolated from peel coffee and Vitex agnuscastus.

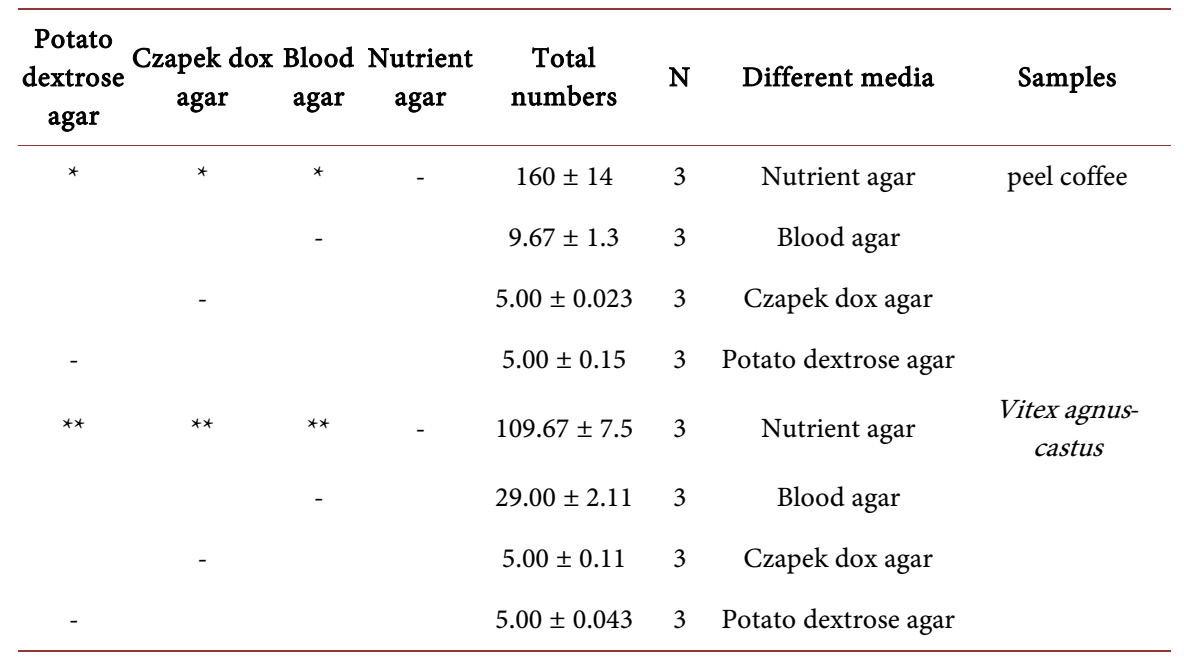

LSD for fungus and bacteria; ${ }^{*}$ interaction $=0.56(p \leq 0.05) ;{ }^{*}$ interaction $=0.01(p \leq 0.01)$.

above that there are statistically significant differences at the level of 0.01 between the average (Vitex agnus-castus) in (nutrient agar) and the average $\mathrm{M}$ in (blood agar, Czapek dox agar, (potato dextrose agar) to the average (peel coffee) in (nutrient agar), where he was the highest. The limits of bacterial contamination given in European pharmacopoeia as reported by [17] are: total aerobic bacteria $\left(10^{5} \mathrm{CFU} / \mathrm{g}\right)$, Enterobacteria and other Gram negative organisms $\left(10^{3}\right.$ CFU/g). Escherichia coli and Salmonella should be absent in the consumed medicinal plants. However, the herbal products under study did not meet these specifications in most cases. The samples were contaminated to varying degrees with pathogenic bacteria. Herbal preparations were however free from bacterial contamination, All herbal medicine (100\%) had bacterial counts in the range of $1.0 \times 10^{7}$ to $4.5 \times 10^{7} \mathrm{CFU} / \mathrm{g}$; while six (70.07\%) showed count between $5 \times 10^{7}$ and $8.5 \times 10^{7} \mathrm{CFU} / \mathrm{g}$. The bacterial counts, in general, ranged between $1.0 \times 10^{7}$ and $1.8 \times 10^{8} \mathrm{CFU} / \mathrm{g}$ respectively. Of concern also is the level of contamination of herbal medicinal preparations by pathogenic Gram negative bacteria. Approximately $58.7 \%$ of the samples were contaminated by $E$. coli, which is an intestinal bacterium and is an indicator for faecal contamination, and $46.7 \%$ were contaminated by Salmonella typhi. Surprisingly, $65.7 \%$ of the samples were contaminated by Staphylococcus aureus, while (19.3\%) were contaminated by Shigella spp. Modernization of health care could benefit from integrating aspects of traditional practices and plant use into healthcare modernization programmes through active involvement of local people. It would facilitate the implementation of culturally appropriate healthcare that respects traditional knowledge and contributes to bio-culturally sustainable development. In addition, there is a need for ethno-botanical research into the rich bio-cultural diversity of the ethnic groups in Asia as rapid assimilation with main stream culture increases. Research focusing on traditionally ignored subjects such as women's health care [21] [22]. In general, ethnobotanical studies often overlook the variety and rela- 
tive importance of plants used in women's healthcare [23] [24], with a few notable exceptions [25] [26]. Research focusing on contamination of herbal medicinal when women use at the postpartum period and the efficacy of these treatments that are both ancient and wide spread, could provide insights that could help to augment and improve both local and Western postpartum care.

\section{Conclusion}

It is known that postpartum period is the most crucial period for the mother and the child. During this period, the immunity of the mother is enhanced and protected by the inhalation of various health benefits herbal medicines. In the present study, the microbial populations of various herbal medicines were determined. The study concluded that, the used herbal medicines contain different levels of microbial pathogens such as Gram Positive and Gram Negative bacteria together with filamentous fungi. However, different levels of public awareness should be made related to the importance of the plant species used such as different methods of plant collection, various preparation techniques, sterile processing techniques. Thereby the medicinal properties of the plants can be protected for a long time.

\section{Conflict of Interest}

We declare that we have no conflict of interest.

\section{References}

[1] Costantine, M.M. (2014) Physiologic and Pharmacokinetic Changes in Pregnancy. Frontiers in Pharmacology, 5, 65. https://doi.org/10.3389/fphar.2014.00065

[2] Antonisamy, P., Duraipandiyan, V., Ignacimuthu, S. and Kim, J.-H. (2015) AntiDiarrhoeal Activity of Friedelin Isolated from Azima tetracantha Lam. in Wistar Rats. South Indian Journal of Biological Sciences, 1, 34-37. https://doi.org/10.22205/sijbs/2015/v1/i1/100440

[3] Balamurugan, R. (2015) Smilax chinensis Linn. (Liliaceae) Root Attenuates Insulin Resistance and Ameliorate Obesity in High Diet Induced Obese Rat. South Indian Journal of Biological Sciences, 1, 47-51. https://doi.org/10.22205/sijbs/2015/v1/i1/100443

[4] Rathi, M.A., Meenakshi, P. and Gopalakrishnan, V.K. (2015) Hepatoprotective Activity of Ethanolic Extract of Alysicarpus vaginalis against Nitrobenzene-Induced Hepatic Damage in Rats. South Indian Journal of Biological Sciences, 1, 60-65. https://doi.org/10.22205/sijbs/2015/v1/i2/100420

[5] Nandhini, V.S. and Stella Bai, G.V. (2015) In-Vitro Phytopharmacological Effect and Cardio Protective Activity of Rauvolfia tetraphylla L. South Indian Journal of Biological Sciences, 1, 97-102. https://doi.org/10.22205/sijbs/2015/v1/i2/100430

[6] Kalaiselvi, V., Binu, T.V. and Radha, S.R. (2016) Preliminary Phytochemical Analysis of the Various Leaf Extracts of Mimusops elengi L. South Indian Journal of Biological Sciences, 2, 24-29. https://doi.org/10.22205/sijbs/2016/v2/i1/100337

[7] Neelamkavil, S.V. and Thoppil, J.E. (2016) Evaluation of the Anticancer Potential of the Traditional Medicinal Herb Isodon coetsa. South Indian Journal of Biological Sciences, 2, 41-45. https://doi.org/10.22205/sijbs/2016/v2/i1/100341 
[8] Valsan, A. and Raphael, K.R. (2016) Pharmacognostic Profile of Averrhoa bilimbi Linn. Leaves. South Indian Journal of Biological Sciences, 2, 75-80. https://doi.org/10.22205/sijbs/2016/v2/i1/100347

[9] Noorudheen, N. and Chandrasekharan, D.K. (2016) Effect of Ethanolic Extract of Phyllanthus emblica on Captan Induced Oxidative Stress in Vivo. South Indian Journal of Biological Sciences, 2, 95-102. https://doi.org/10.22205/sijbs/2016/v2/i1/100353

[10] Santhosh, S.K., Venugopal, A. and Radhakrishnan, M.C. (2016) Study on the Phytochemical, Antibacterial and Antioxidant Activities of Simarouba glauca. South Indian Journal of Biological Sciences, 2, 119-124. https://doi.org/10.22205/sijbs/2016/v2/i1/100358

[11] Sreeshma, P.S., Raphael, K.R. and Baby, A.A. (2016) Pharmacognostic Studies of Leaves of Naravelia zeylanica (Linn) DC. South Indian Journal of Biological Sciences, 2, 179-182. https://doi.org/10.22205/sijbs/2016/v2/i1/100389

[12] World Health Organization (WHO) (1993) Research Guidelines for Evaluating the Safety and Efficacy of Herbal Medicines. World Health Organization Regional Office for the Western Pacific, Manila.

[13] Puthur, J.T. (2016) Antioxidants and Cellular Antioxidation Mechanism in Plants. South Indian Journal of Biological Sciences, 2, 14-17. https://doi.org/10.22205/sijbs/2016/v2/i1/100335

[14] Serasanambati, M. and Chilakapati, S.R. (2016) Function of Nuclear Factor Kappa B (NF-kB) in Human Diseases-A Review. South Indian Journal of Biological Sciences, 2, 368-387. https://doi.org/10.22205/sijbs/2016/v2/i4/103443

[15] De Smet, P.A.G.M. (1999) Overview of Herbal Quality Control. Therapeutic Innovation \& Regulatory Science, 33, 717-724. https://doi.org/10.1177/009286159903300308

[16] Adeleye, I.A., Okogi, G. and Ojo, E.O. (2005) Microbial Contamination of Herbal Preparations in Lagos, Nigeria. Journal of Health, Population and Nutrition, 23, 296-297.

[17] Okunlola, A., Adewoyin, A.B. and Odeku, A.O. (2007) Evaluation of Pharmaceutical and Microbial Qualities of Some Herbal Medicinal Products in South Western Nigeria. Tropical Journal of Pharmaceutical Research, 6, 661-670. https://doi.org/10.4314/tjpr.v6i1.14644

[18] Pearce, M.C., et al. (2004) Distribution of Escherichia coli O157 in Bovine Fecal Parts and Its Impact on Estimates of the Prevalence of Fecal Shedding. Applied Environmental Microbiology, 70, 5737-5743. https://doi.org/10.1128/AEM.70.10.5737-5743.2004

[19] European Agency for the Evaluation of Medicinal Products (1998) Note for Guidance of Quality of Herbal Medicinal Products.

[20] National Agency for Food and Drug Administration and Control (2000) Standard Operating Procedures (NAFDAC SOP), Author Determination of Moisture Contents. Central Drugs and Vaccine Control Laboratory (CDVCL), Lagos, 1-2.

[21] Kennedy, D.A., Lupattelli, A., Koren, G. and Nordeng, H. (2013) Herbal Medicine Use in Pregnancy: Results of a Multinational Study. BMC Complementary and Alternative Medicine, 13, 355. https://doi.org/10.1186/1472-6882-13-355

[22] Zumsteg, I.S. and Weckerle, C.S. (2007) Bakera, a Herbal Steam Bath for Postnatal Care in Minahasa (Indonesia): Documentation of the Plants Used and Assessment of the Method. Journal of Ethnopharmacology, 111, 641-650. https://doi.org/10.1016/j.jep.2007.01.016

[23] John, L.J. and Shantakumari, N. (2015) Herbal Medicines Use during Pregnancy: A 
Review from the Middle East. Oman Medical Journal, 30, 229-236.

https://doi.org/10.5001/omj.2015.48

[24] Inta, A., Shengji, P., Balslev, H., Wangpakapattanawong, P. and Trisonthi, C. (2008) A Comparative Study on Medicinal Plants Used in Akha's Traditional Medicine in China and Thailand, Cultural Coherence or Ecological Divergence. Journal of Ethnopharmacology, 116, 508-517. https://doi.org/10.1016/j.jep.2007.12.015

[25] Roosita, K., Kusharto, C.M., Sekiyama, M., Fachrurozi, Y. and Ohtsuka, R. (2008) Medicinal Plants Used by the Villagers of a Sundanese Community in West Java, Indonesia. Journal of Ethnopharmacology, 115, 72-81. https://doi.org/10.1016/j.jep.2007.09.010

[26] Srithi, K., Balslev, H., Wangpakapattanawong, P., Srisanga, P. and Trisonthi, C. (2009) Medicinal Plant Knowledge and Its Erosion among the Mien (Yao) in Northern Thailand. Journal of Ethnopharmacology, 123, 335-342.

https://doi.org/10.1016/j.jep.2009.02.035

Submit or recommend next manuscript to SCIRP and we will provide best service for you:

Accepting pre-submission inquiries through Email, Facebook, LinkedIn, Twitter, etc. A wide selection of journals (inclusive of 9 subjects, more than 200 journals)

Providing 24-hour high-quality service

User-friendly online submission system

Fair and swift peer-review system

Efficient typesetting and proofreading procedure

Display of the result of downloads and visits, as well as the number of cited articles

Maximum dissemination of your research work

Submit your manuscript at: http://papersubmission.scirp.org/

Or contact jacen@scirp.org 